Editorial

\title{
Contested Concepts, Similar Practices: The Quest for the Global University
}

Higher Education Policy (2008) 21, 429 -438. doi:10.1057/hep.2008.23

\section{Questing for World-Class University Status: A Global Agenda}

In the last decade or so, we have witnessed the emergence of the quest for 'world-class' university status as a movement not only in the West but also in the East. Despite controversy over the meaning and value of this status, no one can deny the fact that global university ranking exercises have become increasingly influential in shaping the lives of academics in general and the choices of students and parents in particular. While many university ViceChancellors and Presidents have declared that we should not entirely rely upon these ranking exercises or league tables as indicators of the academic standards of universities, we simply cannot ignore the growing impact of such global university rankings on how contemporary universities are managed (Deem et al., 2008). Realizing the importance of research and development in the knowledge-based economy, Mohrman et al. (2008) have rightly argued that an Emerging Global Model (EGM) is developing in response to the growing pressures to enhance the global competitiveness of universities across the world. Characterized by eight features, namely, global mission, research intensity, new roles for professors, diversified funding, advancing economic development and increasing knowledge production, worldwide recruitment, increasing complexity, and global collaboration with similar institutions, the worldwide reach of the EGM implies that nation-states have less influence on their universities than in the past. Although there may be disagreement about the extent to which state control of university governance has been diminished, in the last decade or so universities worldwide have undoubtedly experienced significant restructuring in order to concentrate resources to boost a selected few to become 'world-class' institutions (Frank and Gabler, 2007; Stromquist et al., 2007), while many universities have had to struggle for additional funding by commercializing their 'services' or marketizing their 'research outputs' (Etzkowitz and Leydesdorff, 2000; Bok, 2003; Mok and Oba, 2007). It is under such a financial regime that contemporary universities are pressured to compete for international benchmarking with the very best worldwide.

The competition is rendered very severe because there are only a few fully developed EGM universities across the globe, but they certainly perform a 
significant role in leading universities worldwide. Claiming the status of an EGM university is never easy since it requires not only substantial government support but also support from other sectors. In the quest for such global university or world-class university status, many universities worldwide have suffered the negative consequences of university stratification as divisions have emerged in terms of teaching-oriented and research-intensive universities. In order to secure a better position in the university league tables, many nation states in East Asia have concentrated funding on only a select few with the intention of transforming them into 'world-class' universities, while the rest of the universities have received insufficient resources, especially when maintaining an international research profile is costly and organizationally complex (Deem et al., 2008; Mohrman et al., 2008). Critical reflections upon the 'world-class' university movement have shown many unintended social and political consequences. The explosion of university league tables at both national and international levels has clearly led to controversy over the indicators/assessment methods/measurement of global university performance, not to mention debates related to how a 'worldclass university' should be defined. Among various global university rankings published recently, we can easily find a diversity of methodology and assessment indicators being employed. The Shanghai Jiaotong University rankings puts emphasis on research, publications, citations and academic prices (Shanghai Jiaotong, 2007), while the Times Higher Education Supplement Ranking relies heavily on peer evaluation (World University Rankings, 2007). There are other university league tables published in Canada and the USA, and they also differ in terms of assessment criteria and performance yardsticks. Without a consensus on how 'world-class' universities should be defined, the fights among universities worldwide to claim 'world-class' status are really meaningless. Altbach (2004) is therefore right to argue that worldwide inequality is intensified in the midst of the quest for 'world-class' universities, inevitably reproducing centres and peripheries in an unequal environment. It is particularly true when powerful universities dominate the production and distribution of knowledge, while less developed institutions are doomed to find themselves confronting fewer resources and lower academic standards. Our comparative study of how universities in Europe and Asia have attempted to transform themselves into 'world-class' institutions has similarly concluded that 'policy copying' has inevitably led to local problems when 'best practices' identified elsewhere are transferred into fundamentally different contexts (Deem et al., 2008).

\section{In the Quest for Global Competitiveness: National Responses}

With strong intentions to enhance their national competitiveness in the global market place, governments in different parts of the world have started 
comprehensive reviews of their higher education systems and made attempts to transform higher education governance and management style. Dissatisfied with the conventional model of 'state-oriented' and 'highly centralized' approaches in higher education, many governments have tried to 'incorporate' or introduced 'corporatization' and 'privatization' measures to run their state/ national universities, believing that these transformations will make national universities more flexible and responsive to rapid socio-economic changes (Mok and Oba, 2007). Instead of being closely directed by the Ministry of Education or equivalent government administrative bodies, state universities in Asia are now required to become more proactive and dynamic in looking for their own financial resources. Like their Australian and British counterparts, universities in Asia are now under constant pressure to become more 'entrepreneurial' and to look for alternative funding sources from the market, strengthening their partnerships with industry and business (Marginson \& Considine, 2000; Olsen \& Gornitzka, 2006).

Adhering more to the market and corporate principles and practices, universities in Hong Kong are now run on a market-oriented and business corporation model. Universities of this city-state have experienced corporatization and privatization processes, whereby its higher education institutions have proactively engaged in fostering entrepreneurship to search for additional revenue sources from the market (Lee \& Gopinathan, 2005; Mok, 2005a; Chan and Lo, 2007). In order to enhance the efficiency of university governance, the University Grant Committee (UGC), the organization which shapes the direction of higher education development in Hong Kong, has recently subscribed to the notion of 'deep collaboration' among universities, believing that synergy could be achieved if universities in the city-state could better integrate. The UGC even supports university mergers or other forms of restructuring to further establish Hong Kong as a regional hub for excellence in research and scholarship (Lee, 2005; Chan, 2007).

Similarly, the Ministry of Education in Taiwan has decided to change the statutory position of state universities by adopting the principles and practices of corporatization. In order to reduce the state burden in higher education financing, all state universities in Taiwan have to generate additional funds from non-state sectors such as the market and enterprises. Needing to generate sufficient funds to finance their institutions, various kinds of market-driven strategies have been adopted. More recently, the Taiwan government has attempted to restructure its state universities by passing a new University Act to make state universities independent legal entities. Influenced by the Japanese model, state universities in Taiwan are required to establish new governance structures and are also under immense pressure to find additional financial support from non-state channels because the Taiwan government has significantly reduced its funding of them (Lo \& Weng, 2005; Tien, 2006). 
In facing a new market economy context, the Chinese government has simply found the old way of 'centralized governance' in education inappropriate (Yang, 2002). Acknowledging that over-centralization and stringent rules would kill the initiatives and enthusiasm of local educational institutions, the Chinese Communist Party (CCP) called for resolute steps to streamline administration, and to devolve powers to units at lower levels so as to allow them more flexibility to run education. In the last decade or so, higher education in the post-Mao era has experienced structural reforms ranging from curriculum design, financing, promotion of the private/minban sectors in higher education provision, to adopting strategies to develop 'world-class' universities. In order to promote the competitiveness of its higher education in the global marketplace, the Chinese government has introduced various kinds of restructuring exercises to merge universities or to streamline the stubbornly maintained bureaucratic university systems. With the strong intention to identify and develop a few Chinese universities into 'world-class' universities, the government has implemented various reform measures such the '211 project' and the ' 985 project' to concentrate state resources on a few selected top-tier national universities to boost them to become leading universities in the world (Min, 2004; Mok, 2005b; Lo \& Chan, 2006; Chou, 2008).

Like societies in greater China, Japan is not immune from the impact of neoliberalism, managerialism, and economic rationalism, three major ideologies underlying the tidal wave of public sector reforms and the re-invention of government projects across the world. With the intention of making its state university system more responsive and flexible in coping with intensified pressures generated by the growing impact of globalization, the Japanese government has incorporated all state universities since 2004. Central to the transformation of the existing national universities into 'National University Corporations' are three major reform aspects: increased competitiveness in research and education; enhanced accountability together with the introduction of competition; and strategic and functional management of national universities (Oba, 2007).

Higher education restructuring is popular not only among East Asian states but also among Southeast Asian societies. Having reflected upon changing university governance models and evaluated the recent experiences of SMU, the Ministry of Education in Singapore has decided to change the governance models of the existing state universities, namely the National University of Singapore and Nanyang Technological University, by making them independent legal entities through the process of 'corporatization' (Mok, 2005c, 2006a, b). By corporatizing these state universities, the Singapore government hopes that universities on the island state will become more entrepreneurial. Similarly, public universities in Malaysia have started a similar project of 'incorporation' and 'corporatization' since 1998. In the last few years, private 
universities have grown in number, while the public universities are run like corporations. According to Lee (2004), 'the structural changes in the corporatized universities show that collegial forms of governance have been sidelined, entrepreneurial activities have increased, and corporate managerial practices have been institutionalized' (Lee, 2004, 15).

Similar developments could easily be found in other countries in South East Asia. In his recent work, Welch (2007) examines how the higher education systems in Malaysia, Thailand, the Philippines, Indonesia, and Vietnam have been under great pressure to transform because of tremendous demographic changes. Like other more developed economies in East Asia, these South Asian economies have had to reform their higher education systems in order to cope with the challenges of globalization. Yet faced with intensified pressure to assert themselves in the global university league, universities in these South East Asian countries have only found themselves at a greater disadvantage. In particular, when comparing the performance of these South East Asian countries in terms of having patents, papers by citations, and $\mathrm{R} \& \mathrm{D}$ performance with the developed economies in the West, they are certainly far behind the 'threshold'. It is in this wider context that these South Asian countries have begun to rely far more on private or market forces to create additional learning opportunities for higher education. However, the growing prominence of private enterprise in higher education has also raised concerns about quality assurance among the countries in South East Asia (World Bank, 2000; South East Asian Ministers of Education Organization, 2002).

Like their Southeast and East Asian counterparts, universities in North America and Europe have also gone through a similar trend of restructuring. Hawkins (2008) has rightly pointed out that universities in California in the United States of America are confronted with significant financial constraints and many of them have to rely heavily upon non-state funding sources. No longer seeing higher education as a 'public good', Deane Neubauer believes the university's 'good old days' have gone, especially when higher education has become increasingly a 'private good' (Neubauer, 2008). Management reforms and governance change along the lines of neo-liberalism have significantly shaped the way contemporary universities are governed in the West, while many universities have encountered financial difficulty in seeking to sustain their ambitions to become research-led universities able to compete globally. With limited financial support from the state, many universities in the UK, Europe, and in the USA have had to diversify their funding sources by becoming more involved in their so-called 'third mission', that is, engaging in far more entrepreneurial activities by commercializing their research outputs and venturing more in the business and industrial fields or developing more transnational education programmes (Mok, 2005a; Olds, 2007; Knight, 2008; Sirat, 2008). Europe has also seen the start of significant restructuring in higher 
education across the continent. In 1999 the Bologna Declaration began the so-called 'Bologna process' and the harmonization of degree structures across Europe. In 2000 the European Council's 'Lisbon strategy' sought to enhance the role of higher education in the knowledge economy, stressing the importance of innovation in research and development. Subsequently there have been proposals for a European Institute of Technology. All of these initiatives have been taken to ensure that European universities can claim to be world-class (Deem et al., 2008).

\section{About the Issue}

The papers published in this special issue are selected from the International Symposium entitled 'Realising the Global University', which was funded and organized by the Worldwide Universities Network (WUN) in London in November 2007 as part of the 'Ideas and Universities' research project. The editors of this issue want to thank WUN for supporting the symposium and all contributors for their participation.

This special issue sets out against the wider policy context briefly outlined above to examine how selected countries have responded to the growing pressures to achieve 'world-class' university status in order to maintain national competitiveness in the global market place. Rosemary Deem draws upon a wide-ranging body of research to show how ideas about the purposes of universities have shifted radically in large part as a consequence of the unrelenting pressure to claim global standing. Taking the University of Toronto as a case study, Glen Jones demonstrates that different levels of authority within a single system of higher education can orientate themselves quite differently towards the global, the national, and the local. Ka Ho Mok and Ying Chan discuss how governments in China Mainland and Taiwan have attempted to change their higher education policies and adopted various strategies in benchmarking their universities with their global counterparts. David Chan and Pak Tee $\mathrm{Ng}$ review the policy contexts and reform measures adopted by two Tiger economies in East Asia, Hong Kong, and Singapore, as both of these Asian states have tried to become regional hubs of higher education in Asia. Yibing Wang offers critical reflection as a practitioner who has engaged in teaching, research, and administration in Chinese universities on the mainland for a few decades, providing useful insights into how universities in Mainland China have struggled to become globally competitive. Anthony Welch and Zhen Zhang examine issues related to the rise of the Chinese knowledge diaspora in the context of globalization, pointing out the challenges that higher education in China is now facing. Taken together, the papers in this special issue clearly demonstrate that, while the concept 
of the 'world-class' university is deeply contested, similar strategies and practices have been adopted by universities, not only in the West but also in the East, as they respond to intensified pressures imposed on universities worldwide to compete in global rankings.

Going beyond these empirical conclusions, many of the papers also voice dissatisfaction with both the prevalent lack of conceptual coherence and the tendency toward isomorphism, while offering new ways of thinking about higher education and globalization. Thus, Ka Ho Mok and Ying Chan stress the need for deeper and more critical reflection on the trends that they identify in Asia. David Chan and Pak Tee Ng note that internationalization can mean much more than trying to climb a league table. Yibing Wang seeks to identify key steps that will allow universities in the developing world to learn from 'world-class' universities, but not simply copy them without regard to their own identity. Glen Jones argues that in seeking to understand higher education and globalization our unit of analysis should not be limited to the university as an institution; by setting different levels of authority within higher education along one axis and the global, national, and local dimensions along the other, he proposes a global higher education matrix as a framework for analysis that will help us to get to grips with complexity in a systematic way. By focusing on the Chinese intellectual diaspora in Australia, Anthony Welch and Zhen Zhang demonstrate the value of moving away from the university as the unit of analysis, and identify the untapped potential in global knowledge diasporas. Rosemary Deem considers the extent to which higher education researchers have been able to influence policy-makers and university leaders, stressing the need for researchers not only to be critical but also to generate alternative visions that can be broken down into 'easy steps'. The urgent need for further research along the various lines proposed by the contributors is powerfully established.

In light of these conclusions, perhaps the editors may be permitted one further general reflection. All too often globalization is little more than a framework for competition and the striking of bargains. It has been pointed out that there is a real danger that as universities compete to outrank each other in international ranking systems, all therefore tacitly accepting the same criteria by which performance is to be assessed, universities will start to become the same all over the world. Moreover, it has been argued that the criteria currently used create a general drift towards conformity with North American models. There is, however, a counter danger that unthinking acceptance of national traditions and cultural difference may lead to the complete suspension of critical faculties. We then risk drifting into unquestioning and therefore uncomprehending forms of intellectual and moral relativism, and systems so poorly integrated that nothing much happens anyway. How are we to transcend this dilemma, where either all universities become the same and one 
culture dominates, or respect means abandonment of critical perspective and chronic inefficiency? We need to think again about the ideals that should inform globalization. In The Idea of Higher Education Ronald Barnett argued that students should go beyond their core discipline not just for the sake of variety or breadth, but in order to gain a critical perspective on their core discipline. This 'critical interdisciplinarity' would make them more aware of the limitations of their core discipline and ensure that they had not learned simply to follow a set of rules and practices. Barnett put this process at the heart of the emancipatory power of higher education (Barnett, 1990). Could engagement with 'foreign' university traditions perform an analogous role? We need to begin with respect and the effort to understand universities from other cultures on their own terms. But we also need to ask the tough questions. What are degree programmes trying to achieve? What counts as legitimate research, and what methods are involved? How do universities relate to the state?

Crucially, however, we need to make the move to critical self-reflection. In other words, we need to turn these questions back on ourselves in the light of what we find elsewhere. This move to critical self-reflection is what makes globalization potentially so significant, both intellectually and ethically. There is an opportunity here for fundamental re-conceptualization and a re-invention of the transformative power attributed to universities at various times in the past (Wei, 2007). The process of critical self-reflection will only work if all parties are genuinely committed to it, and that requires transparency. It must therefore be clearly embedded in the negotiations by which new structures and procedures are created and in their subsequent management. It is therefore a process that must involve not only students, but also academics and managers. Barnett was arguing for student-centred learning, so the students were the ones to be liberated and empowered by higher education. But, in the context of globalization academics and university leaders need intellectual emancipation and empowerment too. And it is entirely proper for academics and university leaders visiting universities in other cultures for the first time to be learning from the unfamiliar, and to assume the role of the critical student. If all parties see globalization first and foremost in these educational terms, any shift towards common practices can be undertaken not because compliance with a given set of criteria is necessary to compete successfully in a system of rankings but because the practices are held to be genuinely valuable. And where differences are maintained, this can again be because they are deemed worthwhile, and not as an expression of national or local difference for their own sake. If globalization is to benefit and not undermine universities, and if the globalization of universities is to offer an intellectually and ethically influential model for globalization more generally, the process must be driven not by the pursuit of political or financial advantage for a 
particular university or state, but by the pursuit of knowledge and critical reflection.

\author{
Ka Ho Mok ${ }^{\mathrm{a}}$ and Ian P. Wei ${ }^{\mathrm{b}}$ \\ ${ }^{a}$ The University of Hong Kong, Hong Kong, China \\ ${ }^{b}$ University of Bristol, Bristol, $U K$
}

\title{
References
}

Altbach, P. (2004) 'Globalization and the University: myths and realities in an unequal world', Tertiary Education and Management 1: 1-12.

Barnett, R. (1990) The Idea of Higher Education, Buckingham: The Society for Research into Higher Education and Open University Press.

Bok, D. (2003) Universities in the Marketplace: The Commercialization of Higher Education, Princeton, NJ: Princeton University Press.

Chan, D. (2007) 'Global agenda, local response: changing education governance in Hong Kong's higher education', Globalization, Societies \& Education 5(1): 109-124.

Chan, D. and Lo, W. (2007) 'Running universities as enterprises: university governance changes in Hong Kong', Asia Pacific Journal of Education 27(3): 305-322.

Chou, P. (2008) 'Taiwan higher education at the crossroads: implications for China', Journal of Asian Public Policy 1(2): 148-163.

Deem, R., Mok, K.H. and Lucas, L. (2008) 'Transforming higher education in whose image? Exploring the concept of the 'world-class' university in Europe and Asia', Higher Education Policy 21(1): 83-97.

Etzkowitz, H. and Leydesdorff, L. (2000) 'The endless transition: a 'triple helix' of universityindustry-government relations', Research Policy 29(2): 109-123.

Frank, D. and Gabler, J. (2007) Reconstructuring the University: Global Changes in the Academic Core over the 20th Century, Stanford, CA: Stanford University Press.

Hawkins, J. (2008) 'Higher education transformation: some trends in California and Asia', Policy Futures in Education 6(5), forthcoming.

Knight, J. (2008) 'The role of cross-border education in the debate as a public good and private commodity', Journal of Asian Public Policy 1(2): 174-187.

Lee, H.-h. (2005) 'Major issues of university education policy in Hong Kong', Asia Pacific Education Review 6(2): 103-112.

Lee, H.-h. and Gopinathan, S. (2005) 'Reforming university education in Hong Kong and Singapore', in K.-h. Mok and R. James (eds.) Globalization and Higher Education in East Asia, Singapore: Marshall Cavendish Academic, pp. 56-98.

Lee, M.N.N. (2004) Restructuring Higher Education in Malaysia, Penang: School of Educational Studies, Universiti Sains Malaysia.

Lo, Y.-w. and Chan, D. (2006) 'The impact of globalization on higher education in Taiwan and Mainland China', Paper presented at the International Conference on GDPism and Risk: Challenges for Social Development and Governance in East Asia, Bristol, UK, 12-13 July.

Lo, Y.-w.W. and Weng, F.-y. (2005) 'Taiwan's responses to globalization: decentralization and internationalization of higher education', in K.-h. Mok and R. James (eds.) Globalization and Higher Education in East Asia, Singapore: Marshall Cavendish Academic, pp. 137-156.

Marginson, S. and Considine, M. (2000) The Enterprise University: Power, Governance and Reinvention in Australia, Cambridge: Cambridge University Press.

Min, W. (2004) 'Chinese higher education: the legacy of the past and the context of the future', In P. Altbach and T. Umakoshi (eds.) Asian Universities: Historical Perspectives and Contemporary Challenges, Baltimore and London: The Johns Hopkins University Press, pp. 53-84. 
Mohrman, K., Ma, W.H. and Baker, D. (2008) 'The research university in transition: The emerging global model', Higher Education Policy 21(1): 5-27.

Mok, K.-h. (2005a) 'Fostering entrepreneurship: changing role of government and higher education governance in Hong Kong', Research Policy 34: 537-554.

Mok, K.-h. (2005b) 'Globalization and educational restructuring: university merging and changing governance in China', Higher Education 50: 57-88.

Mok, K.-h. (2005c) 'Pro-competition policy tools and state capacity: corporatization of public universities in Hong Kong and Singapore', Policy \& Society 24(3): 1-26.

Mok, K.-h. (2006a) Education Reform and Education Policy in East Asia, London: Routledge.

Mok, K.-h. (2006b) 'The search for new governance: corporatization and privatization experiences in Singapore and Malaysia', Paper presented at the International Workshop on University Restructuring in Asia, 16 January 2006, Research Institute for Higher Education, Hiroshima University.

Mok, K.H. and Oba, J. (2007) 'Paradigm shift or business as usual: the search for new governance in higher education in Asia', Asia Pacific Journal of Education 27(3): 233-236.

Neubauer, D. (2008) 'The historical transformation of public good', Journal of Asian Public Policy 1(2): 127-138.

Oba, J. (2007) 'Incorporation of National Universities in Japan', Asia Pacific Journal of Education 27(3): 291-304.

Olds, K. (2007) 'Global assemblage: Singapore, foreign universities, and the construction of a 'global education hub', World Development 35(6): 959-975.

Olsen, J.P. and Gornitzka, A. (2006) 'Making sense of change in university governance', IAU Horizons 11.4-12.1: 1-3.

Shanghai Jiaotong. (2007) World Top Hundred Universities, Shanghai: Shanghai Jiaotung University.

Sirat, M. (2008) 'Strategic planning directions of Malaysia's higher education: University autonomy in a politically turbulent time', Paper presented at RIHE Seminar, Hiroshima University, June 6, 2008.

South East Asian Ministers of Education Organization. (2002) Private Higher Education: Its Role in Human Resource Development in a Globalised Knowledge Society, Bangkok: SEAMEO.

Stromquist, N.P., Gil-Anton, M., Colatrella, C., Mabokela, R.O. and Smolentseva, C. (2007) 'The academic profession in the globalization age: key trends, challenges and possibilities', in P.G. Altbach and P.M. Peterson (eds.) Higher Education in the New Century: Global Challenges and Innovative Ideas, Rotterdam: Sense Publishers.

Tien, F. (2006) 'Incorporation of National University in Taiwan: challenges for the government and the academics', Paper presented at the International Workshop on University Restructuring in Asia, Hiroshima, Japan, 16 January.

Wei, I.P. (2007) 'Globalisation: past, present and future', Report for The Observatory on Borderless Higher Education, at http://www.obhe.ac.uk/products/reports/ftpdf/2007-09-01_2.pdf.

Welch, A. (2007) 'Governance issues in South East Asian higher education: finance, devolution and transparency in the global era', Asia Pacific Journal of Education 27(3): 237-254.

World Bank. (Task Force on Higher Education and Society). (2000) East Asia Recovery and Beyond, Washington, D.C.: World Bank.

World University Rankings. (2007) The Times Higher Education Supplement, October 2007.

Yang, R. (2002) The Third Delight: Internationalization of Higher Education in China, London: Routledge. 